\title{
Ownership Structure and Capital Structure Decision
}

\author{
Seok Weon Lee ${ }^{1}$ \\ ${ }^{1}$ Division of International Studies, Ewha Woman's University, Seoul, Korea \\ Correspondence: Seok Weon Lee, Division of International Studies, Ewha Woman's University, 11-1 \\ Daehyun-dong, Seodaemun-gu, Seoul, Korea. Tel: 82-2-3277-4456. E-mail: seoklee@ewha.ac.kr
}

Received: February 20, 2015

Accepted: March 3, $2015 \quad$ Online Published: March 10, 2015

doi:10.5539/mas.v9n4p264

URL: http://dx.doi.org/10.5539/mas.v9n4p264

\begin{abstract}
The purpose of this paper is to analyze how the capital structure decision of banking industry is related to the bank ownership structure. From the sample of post-Asian financial crisis of the Korean banking industry, 2000-2008, this study finds that the banks with higher proportion of outside shareholders tend to have greater risk-taking incentives by choosing lower capital ratios. This result suggests a policy implication that bank regulator needs to monitor risk-taking behavior and change of capital structure of the banks with higher proportion of outside shareholdings more carefully to protect them from taking excessively high risk projects. From the results of partitioned sample test, we find that this tendency gets stronger with the increase of outside shareholdings. Thus bank regulator needs to monitor much more carefully the risk-taking behavior of the banks with extremely high proportion of outside shareholdings for the safety and soundness of the banking industry. However, in the test of interaction effects, we find some evidences of the higher proportion of outside shareholding banks to pursue deliberate risk-taking by taking into consideration their nonperforming loan ratio and profitability as well.
\end{abstract}

Keywords: ownership structure, capital structure, outside shareholding, banking industry, risk-taking

\section{Introduction}

Capital structure refers to the way a firm finances its assets through some combination of equity and debt. Capital structure decision is one of the most important corporate policy decisions since it determines the firm's expected future cash flows, and therefore, it affects the firm's stock price by giving some signal about the firm's future profitability to the investors. In corporate finance literature, the following three hypotheses are accepted by researchers to explain the mechanism of determining firms' capital structure. The static trade-off hypothesis of capital structure focuses on finding the point of the optimal capital structure where firm value is maximized. It argues that optimal capital structure of a firm exists, and it is obtained at the point where the benefit of tax shield from the issuance of debt equals the loss from it such as bankruptcy cost and financial distress cost. Rather than finding optimal capital structure, or the point where firm value is maximized, pecking order hypothesis argues that firms prefer the method of internal financing to external financing. In external financing, debt financing is preferred to equity financing. The third hypothesis, agency cost hypothesis of capital structure accepts the existence of optimal capital structure like static trade-off hypothesis. But it argues that optimal capital structure is obtained as the solution of the firm's minimizing the interest conflict between shareholders and debtholders, which is called the principle-agent cost.

Empirical evidences on capital structure decision in the literature are somewhat mixed, however, there are some generally agreed determinants that may explain firms' capital structure decision. Friend and Lang (1988), Crutchley and Hansen (1989), and Angrawal and Nagarajan (1990) found that larger firms tend to use more debt financing. On the other hand, Myers and Majluf (1984), Jensen, Solberg and Zorn (1992) found that the more profitable firms tend to use more equity financing. Many researchers found that the riskier firms tend to use less debt financing, where risk is measured as either the volatility of stock price or earnings. Bradley, Jarrell and Kim (1984), Mehran (1992) are some examples. The researchers providing theoretical arguments regarding capital structure decision include the following ones. The researchers supporting the view of static trade-off hypothesis include Altman (1984, 2002), Myers (1984), Titman and Wessels (1988), and Rajan and Zingales (1995). Those supporting the view of specking order hypothesis include Myers (1984), Myers and Majluf (1984). Agency cost hypothesis of capital structure is originally suggested by Jensen and Meckling (1976). 
This paper tries to add more evidences to the literature of capital structure issues by investigating how the capital structure decision of banking industry is related to the bank ownership structure. Maintaining a stable and safe capital structure is one of the crucial factors for banking industry's soundness and profitability. Therefore, in most countries, capital ratio is the most closely monitored regulatory target variable by bank regulator. Lower capital ratio banks are charged higher deposit insurance premiums and are imposed tighter regulatory restrictions in their business activities. Furthermore, lower capital ratio is believed to give greater incentives to stockholders for risk-taking. Outside shareholders who do not participate in the firm's management decision would have much greater preferences for high risk-taking to maximize the firm's expected profit and the following stock price increase. Overall, in banking industry, capital ratio may be the best variable capturing the bank's risk status and the incentives for risk-taking. In this paper, we try to examine how the capital structure decision of the Korean banks is related the banks' ownership structure. More specifically, we try to find some empirical evidence between banks' capital ratio and the proportion of outside shareholdings.

From the sample of post-Asian financial crisis of the Korean banking industry, 2000-2008, this study finds that the banks with higher proportion of outside shareholders tend to have greater risk-taking incentives by choosing lower capital ratios. This result suggests a policy implication that bank regulator needs to monitor risk-taking behavior and change of capital structure of the banks with higher proportion of outside shareholdings more carefully to protect them from taking excessively high risk projects. From the results of partitioned sample test, we find that this tendency gets stronger with the increase of outside shareholdings. Thus bank regulator needs to monitor much more carefully the risk-taking behavior of the banks with extremely high proportion of outside shareholdings for the safety and soundness of the banking industry. However, in the test of interaction effects, we find some evidences of the higher proportion of outside shareholding banks to pursue deliberate risk-taking by taking into consideration their nonperforming loan ratio and profitability as well.

The next section describes the sample of this paper, testing models and hypotheses. In section 3, we present the empirical results and in section 4 offer concluding remarks.

\section{Sample, Testing Model and Hypothesis}

The sample of this study comes from the Statistics of Bank Management provided by the Korean Financial Supervisory Service during the period 2000-2008. This sample period belongs to post Asian financial crisis after 1997 1999. All the Korean commercial banks including both national and regional banks are included in the sample. There are total seventeen banks in 2000, of which eleven banks are national banks and six banks are regional banks. In 2001, there are fifteen banks, of which nine are national banks and six are regional banks. In 2002, one national bank was closed, and in 2006 one more national bank was closed. In 2007 total thirteen banks remained, of which seven are national and six are regional banks.

To analyze how bank capital structure decision is affected by the bank ownership structure difference, this paper specifies the following functional relationship between capital structure and ownership structure.

\section{Capital structure $=\mathrm{f}($ Ownership structure, Total asset size, Return on asset, Nonperforming loan ratio,} Loan-to-asset ratio)

In the above specification, ownership structure is the main independent variable and the other variables are explanatory variables that are presumed to have some effect on bank capital structure decision. Bank capital structure is defined as the bank capital ratio, and is measured as the total equity divided by total asset. Ownership structure is defined as the proportion of outside shareholdings, and is measured as the amount of common stock hold by outside shareholders divided by total amount of common stock.

The empirical method we use in this study is the multivariate panel regression estimation method during the period 2000-2008 for the Korean banking industry. More specifically, the cross-sectional and time-series data of the sample banks are pooled, and we estimated fixed effect panel regression equation. The method of fixed effect regression is known to solve a potential omitted-variable problem that can happen from a simple OLS type regression when the individual specific component of the residual term is correlated with the regressors of the model such as in the estimation of this paper. This process enables us to get unbiased estimates.

$$
\begin{aligned}
(\text { Capital ratio })_{\mathrm{i}, \mathrm{t}}= & \beta_{0}+\beta_{1}(\text { Outside shareholding })_{\mathrm{i}, \mathrm{t}}+\beta_{2}(\text { Total asset })_{\mathrm{i}, \mathrm{t}}+\beta_{3}(\mathrm{ROA})_{\mathrm{i}, \mathrm{t}} \\
& +\beta_{4}(\text { Nonperforming loans })_{\mathrm{i}, \mathrm{t}}+\beta_{5}(\text { Loan ratio })_{\mathrm{i}, \mathrm{t}}+\varepsilon_{\mathrm{i}, \mathrm{t}}
\end{aligned}
$$

The presumed relations between the independent variables and capital structure are discussed as the following. First, the relation between outside shareholding and capital structure which is the main hypothesis in this paper is expected to have a negative sign. Based on the implication of the literature, if outside shareholders have greater preferences for risk-taking, they would prefer lower capital ratio to maximize expected profit. 
Asset size and capital ratio is expected to have a negative relation. Generally, larger banks have better abilities to diversify and manage the risk of asset portfolios and face lower borrowing cost of capital in financial market. Thus the bankruptcy risk and financial distress cost are lower for larger banks. Thus, other things being equal, larger banks could have more preferences for debt financing which results in lower capital ratio.

Loans are generally considered the riskiest asset category in asset portfolio composition. Thus the banks with higher loan-to-asset ratio would have greater needs to manage their risk by using less debt and more capital financing. Thus the expected sign between loan ratio and capital ratio is positive.

Return on asset (ROA) is used as a control variable for the level of bank profitability on its capital structure decision. Higher profit accumulates more retained earnings, and therefore, capital ratio will increase accordingly. Nonperforming loan ratio is used as a control variable for the overall risk status of the bank.

The summary statistics of the variables used in the empirical analysis, and the expected sign of the regression coefficient on each independent variable with respect to the bank capital ratio based on the preceding arguments are presented in table 1 . The mean value of the capital ratio is 0.0468 , ranging from 0.0241 to 0.0787 . The average outside shareholdings is 0.0152 , ranging from 0 to 0.2632 . The average asset size of the banks is 614,874 billion won, ranging from 14,698 to $2,743,669$. Loan-to-asset ratio and ROA average 0.5296 and 0.5333 , respectively. The mean value of the nonperforming loan ratio is 2.3102 , ranging from 0.4 to 17.4.

Table 1. Summary statistics and the hypothesis for the variables

\begin{tabular}{lcccc}
\hline \multicolumn{1}{c}{ Variables } & Mean & Max & Min & $\begin{array}{c}\text { Expected sign on } \\
\text { regression coefficient }\end{array}$ \\
\hline Capital-to-asset ratio & 0.0468 & 0.0241 & 0.0787 & \\
Outside shareholdings & 0.0152 & 0 & 0.2632 & $\beta_{1}<0$ \\
Total asset & 614,874 & 14,698 & $2,743,669$ & $\beta_{2}<0$ \\
ROA (Return on asset) & 0.5333 & -4.3600 & 3.0500 & $\beta_{3}>0$ \\
NPL (Nonperforming loan ratio) & 2.31 & 0.40 & 17.4 & $\beta_{4}=(?)$ \\
Loan-to-asset ratio & 0.5296 & 0.3574 & 0.6910 & $\beta_{5}>0$ \\
\hline
\end{tabular}

\section{Empirical Results}

\subsection{Full Sample Panel Regression Results}

Table 2 shows the estimation results for the bank capital structure decision focusing on the relationship between bank ownership structure and capital ratio. First, it is presented that the coefficient on outside shareholders is significantly negative. This result says that the banks with higher proportion of outside shareholders tend to have lower capital ratio. Accepting the general notion that lower capital structure would represent greater risk-taking incentives of the firm to maximize profit, this result suggests that the banks with higher proportion of outside shareholders tend to have greater risk-taking incentives. This result may suggest a implication that bank regulator needs to monitor risk-taking behavior and change of capital structure of the banks with higher proportion of outside shareholdings more carefully to protect them from taking excessively high risk projects.

Regarding the other explanatory variables, first it is shown that ROA is negatively related to the bank capital ratio. This result is consistent with what we expected. Higher profit generates more retained earnings, which improves the bank capital ratio. The ratio of nonperforming loans is used as a control variable for the bank general riskiness, however it turns out to be statistically insignificant. Loan ratio turns out to have a significantly positive relation with capital ratio. This indicates that banks with higher loan ratio tend to avoid debt financing and prefer maintaining higher capital ratio. Generally, loans are the riskiest type of asset categories, and therefore, when loan ratio is high banks would have greater incentives to use less debt in terms of risk management. Unlike our expectation, bank asset size turned out to be significantly positively related to capital ratio. We presume this result is attributed to the fact that during the sample period of this study, tighter regulatory monitoring has been imposed on larger banks in the early 2000s to monitor larger banks' behavior more closely after riskier, smaller banks have been acquired by larger banks through Asian financial crisis period. This result can be understood by considering that takeover of financially unhealthy and small banks by financially healthy and large banks is one of the prevailing methods of restructuring Korean banking industry to overcome the financial crisis in the late 1990s. Improving bank capital ratio is the main regulatory target of bank regulator to recover the soundness of Korean banks. Thus maintaining a decent level of capital ratio is one of the very important corporate policies of large banks to avoid heavy regulatory pressure from the regulator. 
Table 2. Panel regression results for the full sample

\begin{tabular}{|c|c|c|}
\hline & Coefficient & $\mathrm{t}$ - statistic \\
\hline Intercept & $0.0256^{* * *}$ & 3.9257 \\
\hline Outside shareholdings & $-0.0639 * * *$ & -3.2348 \\
\hline Total asset & $4.19 \times 10^{-9 * * *}$ & 3.4727 \\
\hline ROA & $0.0057 * * *$ & 5.1454 \\
\hline NPL & 0.0002 & 0.5485 \\
\hline Loan-to-asset ratio & $0.0304 * * *$ & 2.7192 \\
\hline $\mathrm{R}^{2}$ & \multirow{2}{*}{\multicolumn{2}{|c|}{$\begin{array}{c}0.4723 \\
21.6607 * * *\end{array}$}} \\
\hline F-statistic & & \\
\hline
\end{tabular}

$*, * *, * * *$ indicate statistical significance at the 10,5, or $1 \%$ significance level, respectively.

\subsection{Interaction Effect Tests}

To examine further the relationship between bank ownership structure and capital structure decision, we perform interaction effect test between the proportion of outside shareholders and the other explanatory variables for bank capital structure. The results are presented in table 3. First table in table 3 shows that the coefficient on the interaction variable, 'outside shareholding $\mathrm{x}$ ROA', is significantly negative. This result indicates that when the bank ROA is low, the bank with higher proportion of outside shareholders may not decrease capital ratio as much as they do when ROA is high. This result can be interpreted to imply that even though the banks with higher proportion of outside shareholding have greater incentives for higher risk-taking by maintaining lower capital ratio which is reflected by the significantly negative coefficient on outside shareholdings, they also have the motivation for risk management and control by taking into consideration their profitability as well.

Similar implication is found form the second table which focuses on the interaction variable between outside shareholding and NPL, 'outside shareholding x NPL'. It is shown that the coefficient on the interaction variable is significantly positive. This result shows that when the bank NPL is high, higher proportion of outside shareholding is not related to the decrease of capital ratio. In other words, when the bank NPL is high, the bank with higher proportion of outside shareholders may not decrease capital ratio as much as they do when NPL is low. This result says that even though the banks with higher proportion of outside shareholding have greater incentives for higher risk-taking by maintaining lower capital ratio, they also have the motivation for risk management and control by taking into consideration their risk status as well.

The above results on interaction effect test may be interpreted as an evidence for supporting deliberate risk-taking behavior of the banks with higher proportion of outside shareholdings. The other two interaction variables, 'outside shareholding $\mathrm{x}$ loan ratio' and 'outside shareholding $\mathrm{x}$ asset size', have insignificant relations with capital ratio, and the results are available for the authors upon request.

Table 3. Panel regression results for the full sample (Interaction effect test)

\begin{tabular}{|c|c|c|}
\hline & Coefficient & t- statistic \\
\hline Intercept & $0.0253 * * *$ & 3.9424 \\
\hline Outside shareholdings & $-0.0584 * * *$ & -2.9688 \\
\hline Total asset & $4.14 \times 10^{-9} * * *$ & 3.4795 \\
\hline ROA & $0.0069 * * *$ & 5.5788 \\
\hline NPL & 0.0003 & 0.6842 \\
\hline Loan-to-asset ratio & $0.0294 * * *$ & 2.6645 \\
\hline Outside shareholding $\times$ ROA & $-0.0364 * *$ & -2.0638 \\
\hline $\mathrm{R}^{2}$ & \multicolumn{2}{|c|}{$\begin{array}{c}0.4904 \\
102467 * * *\end{array}$} \\
\hline F-statistic & \multicolumn{2}{|c|}{$19.2467 * * *$} \\
\hline \multicolumn{3}{|c|}{$*, * *, * * *$ indicate statistical significance at the 10,5, or $1 \%$ significance level, respectively. } \\
\hline & Coefficient & t- statistic \\
\hline Intercept & $0.0262 * * *$ & 4.0576 \\
\hline Outside shareholdings & $-0.1134 * * *$ & -3.3778 \\
\hline Total asset & $4.19 \times 10^{-9} * * *$ & 3.5072 \\
\hline
\end{tabular}




\begin{tabular}{lcc}
\hline ROA & $0.0061 * * *$ & 5.4535 \\
NPL & 0.0001 & 0.2733 \\
Loan-to-asset ratio & $0.0293^{* * *}$ & 2.6441 \\
Outside shareholding x NPL & $0.0132^{*}$ & 1.8141 \\
$\mathrm{R}^{2}$ & & 0.4864 \\
F-statistic & \multicolumn{2}{c}{$18.9409^{* * *}$} \\
* $^{* *}, * * *$ indicate statistical significance at the 10,5, or $1 \%$ significance level, respectively.
\end{tabular}

\subsection{Partitioned Sample Test}

In this section, we divide the full sample into two groups (higher outside shareholding banks vs lower outside shareholding banks) and examine whether there is any difference in the capital structure decision between the two groups. Each bank belongs to one group based on its proportion of outside shareholdings compared to the median value of the full sample banks' proportion of outside shareholdings for each year. Table 4 shows that the coefficient on outside shareholdings is greater and more significant for the group of the banks with higher outside shareholdings. This result suggests that the risk-taking incentives of the banks by decreasing capital ratio appear to be greater for the banks with extremely high proportion of outside shareholdings. This finding suggests a policy implication that bank regulator needs to monitor much more carefully the risk-taking behavior and capital structure of the banks with extremely high proportion of outside shareholdings for the safety and soundness of the banking industry.

Table 4. Panel regression results for the partitioned sample

\begin{tabular}{lcccc}
\hline & \multicolumn{2}{c}{ Higher outside shareholding banks } & \multicolumn{2}{c}{ Lower outside shareholding banks } \\
\hline & Coefficient & t- statistic & Coefficient & t- statistic \\
Intercept & $0.0358^{* * *}$ & 3.3971 & $0.0411^{* * *}$ & 4.0174 \\
Outside shareholdings & $-1.3581^{* * *}$ & -4.9027 & $-0.0116^{*}$ & -1.6926 \\
Total asset & $3.67 \times 10^{-9 * * *}$ & 3.4891 & $2.9017 \times 10^{-9 * * *}$ & 2.9913 \\
ROA & $0.0029^{* * *}$ & 4.2895 & $0.0103 * * *$ & 5.3829 \\
NPL & 0.0016 & 0.6221 & -0.0001 & -0.2875 \\
Loan-to-asset ratio & $0.0118^{* * *}$ & 1.9375 & $0.0207 * * *$ & 2.1005 \\
$\mathrm{R}^{2}$ & \multicolumn{2}{c}{0.4891} \\
F-statistic & \multicolumn{2}{c}{$15.5862^{* * *}$} \\
$*, * *, * * *$ indicate statistical significance at the 10,5, or $1 \%$ significance level, respectively.
\end{tabular}

$*, * *, * * *$ indicate statistical significance at the 10,5, or $1 \%$ significance level, respectively.

\section{Summary and Concluding Remarks}

The purpose of this paper is to analyze how the capital structure decision of banking industry is related to the bank ownership structure. From the sample of post-Asian financial crisis of the Korean banking industry, 2000-2008, this study finds that the banks with higher proportion of outside shareholders tend to have greater risk-taking incentives by choosing lower capital ratios. This result suggests a policy implication that bank regulator needs to monitor risk-taking behavior and change of capital structure of the banks with higher proportion of outside shareholdings more carefully to protect them from taking excessively high risk projects. From the results of partitioned sample test, we find that this tendency gets stronger with the increase of outside shareholdings. Thus bank regulator needs to monitor much more carefully the risk-taking behavior of the banks with extremely high proportion of outside shareholdings for the safety and soundness of the banking industry. However, in the test of interaction effects, we find some evidences of the higher proportion of outside shareholding banks to pursue deliberate risk-taking by taking into consideration their nonperforming loan ratio and profitability as well.

\section{References}

Altman, E. (1984). A Further Empirical Investigation of the Bankruptcy Cost Question. The Journal of Finance, 1067-1089. http://dx.doi.org/10.1111/j.1540-6261.1984.tb03893.x

Angrawal, A., \& Nagarajan, N. J. (1990). Corporate Capital Structure, Agency Costs and Ownership Control. The Journal of Finance, 1325-1330. http://dx.doi.org/10.1111/j.1540-6261.1990.tb02441.x

Bradley, M., Jarrell, G., \& Kim, E. H. (1984). On the Existence of an Optimal Capital Structure: Theory and 
Evidence. The Journal of Finance, 857-878. http://dx.doi.org/10.1111/j.1540-6261.1984.tb03680.x

Crutchley, C. E., \& Hansen, R. S. (1989). A Test of the Agency Theory of Managerial Ownerhsip, Corporate Leverage and Corporate Dividends. Financial Management, 36-46. http://dx.doi.org/10.2307/3665795

Friend, I., \& Lang, L. (1988). An Empirical Test of the Impact of Managerial Self-Interest on Corporate Capital Structure. The Journal of Finance, 271-281. http://dx.doi.org/10.1111/j.1540-6261.1988.tb03938.x

Jensen, G. R., Solberg, D. P., \& Zorn, T. S. (1992). Simultaneous Determination of Insider Ownership, Debt, and Dividend Policies. Journal of Financial and Quantitative Analysis, 247-263. http://dx.doi.org/10.2307/2331370

Jensen, M., \& Meckling, W. (1976). The Theory of Firm Value: Managerial Behavior, Agency Costs and Ownership Structure. Journal of Financial Economics, 305-360. http://dx.doi.org/10.1016/0304-405X(76)90026-X

Mehran, H. (1992). Executive Incentive Plans, Corporate Control and Capital Structure. Journal of Financial and Quantitative Analysis, 539-560. http://dx.doi.org/10.2307/2331139

Modigliani, F., \& Miller, M. (1958). The Cost of Capital, Corporation Finance and the Theory of Investment. The American Economic Review, 48, 261-297.

Myers, S. (1984). The capital structure Puzzle. The Journal of Finance, 39, 575-592. http://dx.doi.org/10.2307/2327916

Myers, S., \& Majluf, N. S. (1984). Corporate Financing and Investment Decisions When Firms Have Information That Investors Do Not Have. Journal of Financial Economics, 187-221. http://dx.doi.org/10.1016/0304-405X(84)90023-0

Rajan, R., \& Zingales, L. (1977). What Do Know about Capital Structure? Some 26 Evidence from International Data. The Journal of Finance, 1421-1460.

Ravid, S. A. (1988). On Interactions of Production and Financial Decisions. Financial Management, 87-99. http://dx.doi.org/10.2307/3666075

Titman S., \& Wessel, R. (1988). The Determinants of Capital Structure Choices. The Journal of Finance, 1-19. http://dx.doi.org/10.1111/j.1540-6261.1988.tb02585.x

\section{Copyrights}

Copyright for this article is retained by the author(s), with first publication rights granted to the journal.

This is an open-access article distributed under the terms and conditions of the Creative Commons Attribution license (http://creativecommons.org/licenses/by/3.0/). 